\title{
Front Matter: Volume 8516
}

, "Front Matter: Volume 8516," Proc. SPIE 8516, Remote Sensing System Engineering IV, 851601 (23 October 2012); doi: 10.1117/12.2008669

SPIE Event: SPIE Optical Engineering + Applications, 2012, San Diego, California, SPIE. United States 


\section{PROCEEDINGS OF SPIE}

\section{Remote Sensing System Engineering IV}

Philip E. Ardanuy

Jeffery J. Puschell

Hal J. Bloom

Editors

12-13 August 2012

San Diego, California, United States

Sponsored and Published by

SPIE 
The papers included in this volume were part of the technical conference cited on the cover and title page. Papers were selected and subject to review by the editors and conference program committee. Some conference presentations may not be available for publication. The papers published in these proceedings reflect the work and thoughts of the authors and are published herein as submitted. The publisher is not responsible for the validity of the information or for any outcomes resulting from reliance thereon.

Please use the following format to cite material from this book:

Author(s), "Title of Paper," in Remote Sensing System Engineering IV, edited by Philip E. Ardanuy, Jeffery J. Puschell, Hal J. Bloom, Proceedings of SPIE Vol. 8516 (SPIE, Bellingham, WA, 2012) Article CID Number.

ISSN: 0277-786X

ISBN: 9780819492333

Published by

SPIE

P.O. Box 10, Bellingham, Washington 98227-0010 USA

Telephone +1 3606763290 (Pacific Time) · Fax +1 3606471445

SPIE.org

Copyright (C) 2012, Society of Photo-Optical Instrumentation Engineers.

Copying of material in this book for internal or personal use, or for the internal or personal use of specific clients, beyond the fair use provisions granted by the U.S. Copyright Law is authorized by SPIE subject to payment of copying fees. The Transactional Reporting Service base fee for this volume is $\$ 18.00$ per article (or portion thereof), which should be paid directly to the Copyright Clearance Center (CCC), 222 Rosewood Drive, Danvers, MA 01923. Payment may also be made electronically through CCC Online at copyright.com. Other copying for republication, resale, advertising or promotion, or any form of systematic or multiple reproduction of any material in this book is prohibited except with permission in writing from the publisher. The CCC fee code is 0277-786X/12/\$18.00.

Printed in the United States of America.

Publication of record for individual papers is online in the SPIE Digital Library.

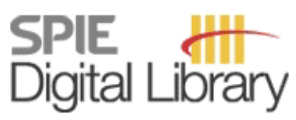

SPIEDigitalLibrary.org

Paper Numbering: Proceedings of SPIE follow an e-First publication model, with papers published first online and then in print and on CD-ROM. Papers are published as they are submitted and meet publication criteria. A unique, consistent, permanent citation identifier (CID) number is assigned to each article at the time of the first publication. Utilization of CIDs allows articles to be fully citable as soon as they are published online, and connects the same identifier to all online, print, and electronic versions of the publication. SPIE uses a six-digit CID article numbering system in which:

- The first four digits correspond to the SPIE volume number.

- The last two digits indicate publication order within the volume using a Base 36 numbering

system employing both numerals and letters. These two-number sets start with 00, 01, 02, 03, 04, 05, 06, 07, 08, 09, 0A, OB ... 0Z, followed by 10-1Z, 20-2Z, etc.

The CID Number appears on each page of the manuscript. The complete citation is used on the first page, and an abbreviated version on subsequent pages. Numbers in the index correspond to the last two digits of the six-digit CID Number. 


\section{Contents}

$\checkmark$ Conference Committee

vii Introduction

\section{SESSION 1 FUTURE EARTH OBSERVING SYSTEMS}

851602 Test plan for a calibration demonstration system for the reflected solar instrument for the climate absolute radiance and refractivity observatory [8516-1]

K. Thome, J. McCorkel, J. Hair, B. McAndrew, A. Daw, D. Jennings, D. Rabin, NASA

Goddard Space Flight Ctr. (United States)

851604 Projected performance of an enhanced VIIRS with spectral bands near $6.7 \mu \mathrm{m}$ for measuring atmospheric water vapor distribution [8516-3]

J. J. Puschell, S. J. Herbst, Raytheon Space \& Airborne Systems (United States)

851605 Next generation along track scanning radiometer - SLSTR [8516-4]

J. Frerick, J. Nieke, C. Mavrocordatos, B. Berruti, C. Donlon, ESA (Netherlands); M. Cosi, SELEX Galileo S.p.A. (Italy); W. Engel, Jena Optronik GmbH (Germany); S. Bianchi, Thales Alenia Space (France); D. Smith, Rutherford Appleton Lab. (United Kingdom)

851606 Expected performance of the Visible Infrared Imager Radiometer Suite (VIIRS) without detector sample aggregation [8516-5]

J. H. Steele, J. J. Puschell, Raytheon Space \& Airborne Systems (United States);

C. F. Schueler, Orbital Sciences Corp. (United States); S. W. Miller, K. Grant, Raytheon Intelligence and Information Systems (United States); T. F. Lee, Naval Research Lab. (United States)

\section{SESSION 2 LESSONS LEARNED}

851607 FD-CHIRP: hosted payload system engineering lessons (Invited Paper) [8516-6]

C. F. Schueler, Orbital Sciences Corp. (United States)

851608 Lessons learned from the 705-km fleet [8516-7]

M. A. Vincent, Raytheon Intelligence \& Information Systems (United States)

\section{SESSION 3 NEW TOOLS, NEW APPROACHES}

8516 OA The EIP: a standard experimenter interface panel for NASA airborne science [8516-9]

J. B. Forgione, NASA Ames Research Ctr. (United States); J. R. Grose, J. S. Myers,

C. E. Sorenson, Univ. of California, Santa Cruz (United States); R. G. Vogler, Arctic Slope

Regional Corp. (United States) 
8516 OB CubeSat modules for multispectral environmental imaging from polar orbit [8516-11] J. J. Puschell, Raytheon Space \& Airborne Systems (United States) and California Polytechnic State Univ. (United States); E. Stanton, California Polytechnic State Univ. (United States)

8516 0C Day/night band imager for a CubeSat [8516-10]

E. J. Stanton, California Polytechnic State Univ. (United States); J. J. Puschell, Raytheon Space \& Airborne Systems (United States) and California Polytechnic State Univ. (United States)

$85160 \mathrm{O}$ A real-time multispectral imaging system for low- or mid-altitude remote sensing [8516-12] D. Yi, Xiamen Torch Hi-tech (China); L. Kong, Minlang Technology and Instrument Ltd. Xiamen (China)

\section{SESSION $4 \quad$ ACTIVE REMOTE SENSING}

8516 OF Polarization effects induced by a two-mirror laser beam scanner [8516-14]

S. Gimbal, Q. Li, A. Petrova-Mayor, California State Univ., Chico (United States)

$85160 \mathrm{G}$ Laser-induced plasma shutter for infra red range-resolved DIAL [8516-15]

T. Gasmi, Saint Louis Univ., Madrid Campus (Spain); K. Gasmi, King Fahd Univ. of Petroleum \& Minerals (Saudi Arabia)

$8516 \mathrm{OH} \quad$ Photonic services, their enablers and applications [8516-20]

J. Vojtech, V. Smotlacha, P. Skoda, CESNET (Czech Republic); A. Kuna, Institute of Photonics and Electronics of the ASCR, v.v.i. (Czech Republic); M. Hula, S. Sima, CESNET (Czech Republic)

8516 Ol Polarization sensitivity of Visible Infrared Imager Radiometer Suite (VIIRS) Flight Unit 1 [851622]

E. J. Novitsky, S. Herbst, J. B. Young, J. J. Puschell, Raytheon Space \& Airborne Systems (United States); E. C. Fest, Raytheon Missile Systems (United States); B. Guenther, Stellar Solutions at JPSS Program (United States)

POSTER SESSION

8516 OL RSI Sun exposure survivability [8516-19]

C. Liu, J. Ling, National Space Organization (Taiwan); M.-Y. Hsu, Instrument Technology Research Ctr. (Taiwan); M.-Y. Yeh, C.-H. Chang, National Space Organization (Taiwan)

$85160 \mathrm{M}$ Study of bonding positions of isostatic mounts on a lightweight primary mirror [8516-13] C. Y. Chan, National Applied Research Labs. (Taiwan); Y. C. Chen, National Central Univ. (Taiwan); S. T. Chang, T. M. Huang, M. Y. Hsu, National Applied Research Labs. (Taiwan) 


\section{Conference Committee}

Symposium Chair

Zakya H. Kafafi, National Science Foundation (United States)

Conference Chairs

Philip E. Ardanuy, Raytheon Intelligence \& Information Systems (United States)

Jeffery J. Puschell, Raytheon Space \& Airborne Systems (United States)

Conference Cochair

Hal J. Bloom, Earth Resources Technology, Inc. (United States)

Conference Program Committee

Richard A. Anthes, National Center for Atmospheric Research (United States)

Robert M. Atlas, National Oceanic and Atmospheric Administration (United States)

Stephen A. Cota, The Aerospace Corporation (United States)

Gerald J. Dittberner, Harris Corporation (United States)

R. Patrick Earhart, Ball Corporation (United States)

William B. Gail, Microsoft Corporation (United States)

Om P. Gupta, Iridium Satellite LLC (United States)

M. Gregory Hammann, GeoEye, Inc. (United States)

Wei-Min Hao, U.S. Forest Service (United States)

Allen H.-L. Huang, University of Wisconsin-Madison (United States)

Gerard Jansson, Intelsat Global Service Corporation (United States)

K. Dieter Klaes, European Organisation for the Exploitation of Meteorological Satellites (Germany)

Stephen A. Mango, NOAA / NESDIS Office of Satellite Operations (United States)

Jens Nieke, European Space Research and Technology Center (Netherlands)

John C. Petheram, Lockheed Martin Space Systems Company (United States)

Carl F. Schueler, Orbital Sciences Corporation (United States)

Song Yang, NASA Goddard Space Flight Center (United States) 
Session Chairs

1 Future Earth Observing Systems

Jeffery J. Puschell, Raytheon Space \& Airborne Systems (United States)

2 Lessons Learned

Philip E. Ardanuy, Raytheon Intelligence \& Information Systems (United States)

3 New Tools, New Approaches

Carl F. Schueler, Orbital Sciences Corporation (United States)

4 Active Remote Sensing

Jeffery J. Puschell, Raytheon Space \& Airborne Systems (United States) 


\section{Introduction}

This volume contains the proceedings for Remote Sensing System Engineering IV held in San Diego, California on 12 August 2012, as part of the Optical Engineering + Applications section of SPIE Optics +Photonics. This fourth RSSE conference resumed the series started in 2008, following an interruption in 2011.

The overarching goal of the conference was to provide a forum for exchanging critical lessons learned and best practices in the systems engineering of ground-, air-, and space-based remote sensing systems. Additional goals were to enable sharing existing and emerging design approaches, engineering methods, tools, and future trends for engineering of remote sensing systems.

Topics included: (1) systems engineering best practices and lessons learned; (2) system architecture and design; (3) requirements, performance metrics, and measures of success; (4) modeling and simulation tools and methods; (5) design and integration of distributed architectures; (6) use of commercial assets in future remote sensing systems; (7) bridging and balancing across the science-toengineering and technologist-to-end-user valleys of "death and lost opportunities"; and (8) the end user, effective data/information/system utilization, and optimum return on investment.

A total of 19 papers were presented in five sessions, including a poster session. A diverse group of international researchers from government, academia, and industry participated in the conference. The range of topics presented in this conference continued to grow and included very timely and exciting papers on system engineering of CubeSat-based imagers for environmental imaging and remote sensing that offer promise for significant cost and schedule reduction in developing future remote sensing systems, discussion of lessons learned from the recent CHIRP hosted payload mission for the USAF and a next-generation alongtrack scanning radiometer called SLSTR along with system simulation approaches for assessing contributions of future operational remote sensing systems to weather forecasting, a new multispectral imager based on computational optics methods and a description of plans for testing a calibration demonstration system for instruments measuring reflected sunlight in future climate monitors.

We thank all of the participants who made this conference successful, especially the cochairs, program committee, and authors.

Jeffery J. Puschell
Philip E. Ardanuy 
Proc. of SPIE Vol. $8516851601-8$

Downloaded From: https://www.spiedigitallibrary.org/conference-proceedings-of-spie on 26 Apr 2023 Terms of Use: https://www.spiedigitallibrary.org/terms-of-use 